\title{
Medium chain fatty acids and fatty acid esters as potential markers of alcoholic fermentation of white wines
}

\author{
Cs. Csutoras $^{1 *}$ (), N. Bakos-Barczi ${ }^{2}$ and B. Burkus ${ }^{2}$ \\ ${ }^{1}$ Department of Chemistry and Physics, Eszterhazy Karoly Catholic University, Eszterházy tér. 1, \\ H-3300 Eger, Hungary \\ ${ }^{2}$ Eger Crown Winehouse Ltd., Bartók Béla út. 162, H-1224 Budapest, Hungary
}

\section{ORIGINAL RESEARCH PAPER}

Received: June 8,2021 • Accepted: September 6, 2021

Published online: December 17, 2021

(c) 2021 The Author(s)

\section{ABSTRACT}

Aroma components of wines play an important role in the sensory quality of wines. In our paper we investigate the effect of commercially available yeast nutrients under different fermentation parameters. Caproic acid, caprylic acid, capric acid, and different fatty acid esters were used as markers of the alcoholic fermentation process. The optimal temperature for the fermentation of different white wines was at $15-16^{\circ} \mathrm{C}$, in the case of examined wines lower concentrations of fatty acids and fatty acid esters were found at this temperature. At $25-26^{\circ} \mathrm{C}$ fermentation temperature very high concentrations of fatty acids and fatty acid esters were detected. Applying different nitrogen-containing wine additives we managed to achieve better aroma profiles for white wines even using musts of lower quality.

\section{KEYWORDS}

medium chain fatty acid, wine fermentation, wine quality, gas chromatography, wine aroma

\footnotetext{
*Corresponding author. Tel.: +3636520471. E-mail: csutoras.csaba@uni-eszterhazy.hu
} 


\section{INTRODUCTION}

In winemaking the main objective is to optimise product quality, which is difficult to quantify. Wine tasting is a traditional way to assess the characteristics of wine, but it is difficult, imprecise, and time-consuming. Major advances have been made in the description of quality markers of wines (Francis and Newton, 2005; Swiegers and Pretorius, 2007; Merkyte et al., 2020). The control of technological parameters, such as sugar exhaustion, duration of fermentation, and amount of energy required to regulate fermentation temperature, is also of interest. Many works have shown that fast fermentation may be detrimental to wine quality, especially for white wines, but too long fermentation can increase the risk of wine spoilage. In recent years, winemakers have focused on flavour development in ripening grapes and during fermentation process.

The range of temperatures used for wine fermentations is from $15^{\circ} \mathrm{C}$ for white wines to more than $30^{\circ} \mathrm{C}$ for red wines. The fermentation temperature of some prestigious oxidative white wines (Tokaj, Somló) can be far above $20^{\circ} \mathrm{C}$. An increase in production of volatile compounds (esters, acetates) was reported by some researchers during alcoholic fermentation at lower temperatures (Torija et al., 2003; Samoticha et al., 2019). Lower temperatures can be used by winemakers to enhance the production of volatile compounds, improving the aromatic profile of wine. Concentrations of some high-boiling point acids and esters increase with increasing fermentation temperature (Killian and Ough, 1979; Pérez-Navarro et al., 2020). Many ethyl esters are especially odour-active and may contribute to sensory response (Gomez et al., 1994). Medium chain fatty acids (MCFA) and their ethyl esters are present in low concentrations in the aroma profile of wines. MCFA ethyl esters contribute to the fruity aroma of wines. High concentrations of MCFAs can inhibit yeast growth and lead to decrease of quality (Viegas et al., 1989). The formation of these acids within the cells depends on the yeast species, strains, and temperature (Torija et al., 2003; Tronchoni et al., 2012), but their accumulation in wine has scarcely been studied. Wine fermentation at low temperatures results in the formation of medium chain fatty acid containing lipids (Tronchoni et al., 2012). Small changes in concentration of unsaturated fatty acids cause a significant influence on the aromatic component of wines (Liu et al., 2021). The inhibiting effect of MCFAs on yeasts was thoroughly investigated, $10 \mathrm{mg} \mathrm{L}^{-1}$ dose of MCFA mixture had a toxic effect on Saccharomyces cerevisiae (Baron et al., 2017). The effect of a mixture of MCFA at the end of the alcoholic fermentation process on the content of carbonyl compounds in wine was also investigated (Licek et al., 2020). During the production of red wines (Carmenere), authors observed the increased formation of MCFAs at elevated temperatures, therefore they suggest to keep temperature under $28^{\circ} \mathrm{C}$ (Restrepo et al., 2019).

The addition of nutrients may be useful, particularly to avoid stuck fermentations. The technology is widely applied, and the number of commercially available products is increasing. The addition of ammonium salts (diammonium phosphate (DAP)) is an efficient way to increase fermentation rate and lower duration of fermentation (Bely et al., 1990; Cramer et al., 2002; Gobert et al., 2019). The timing of nitrogen source addition is crucial, if nitrogen is added at the time of inoculation, it is metabolised and used for additional yeast growth. Addition of yeast wall preparations is also often applied during fermentation. It serves as nutrient source for fermentation.

Assimilable nitrogen content of must is crucial for fermentation process, only ammonia, ammonium ion, and most of the amino acids can be utilised by yeasts under fermentative 
conditions. At low nitrogen concentration, yeasts produce in high concentrations sulphurcontaining odour compounds (Henschke and Jiranek, 1993; Santamaría et al., 2020), but to the best of our knowledge, the effect of assimilable nitrogen content on the MCPAs has not been published.

In our paper we focused on the investigation of medium chain fatty acids and their ethyl esters during alcoholic fermentation of white wines using reductive technology. Effect of temperature and oenological nutrients on MCFA and MCFA ethyl ester content was investigated.

\section{MATERIALS AND METHODS}

\subsection{Reagents and oenological materials}

Chemical reagents and standards were purchased from VWR International Inc. Yeast strains and other oenological materials were purchased from a local winery trader (Interker-Wine Ltd., Hungary). "Vinoferm Crio" S. cerevisiae hybrid (04/2019 - Essedielle Ltd. - www.essedielle.com) was used for fermentations.

\subsection{Alcoholic fermentation at different temperatures}

White grape musts were produced by Eger Crown Winehouse Ltd., the produced row musts were used in our experiments. To the destemmed and crushed grapes sodium metabisulphite was added ( $10 \mathrm{~g} / 100 \mathrm{~kg}$ grape), then it was immediately pressed. After decanting, overnight musts were inoculated with yeast strains of $S$. cerevisiae (Vinoferm Crio). The alcoholic fermentations for the winemaking process were carried out in glass wine fermentors $(10 \mathrm{~L})$. Three-three carboys containing different white wine musts were kept at cellar temperature $\left(15-16^{\circ} \mathrm{C}\right)$ and at ambient temperature $\left(25-26^{\circ} \mathrm{C}\right)$. After 30 days of fermentation, wines were decanted, sulphurised $\left(100 \mathrm{mg} \mathrm{L}^{-1}\right.$ sodium metabisulphite), and analysed by GC-MS.

\subsection{Fermentations applying nitrogen supplements}

The previously applied method was used to prepare raw musts for the experiments from white grape (purposely low-quality Chardonnay - with low sugar-content $\left(180 \mathrm{~g} \mathrm{~L}^{-1}\right)$ was chosen). To the raw musts $(4 \mathrm{~L})$ inoculated with yeast (S. cerevisiae - Vinoferm Crio) different additives were added on the starting day and on the $8^{\text {th }}$ day of fermentation. Applied additives and their amounts are summarised in Table 1.

The glass wine fermentors were kept at cellar temperature $\left(15-16^{\circ} \mathrm{C}\right)$. Samples for basic oenological parameters were taken on the $8^{\text {th }}$ day of fermentation, then at the end of fermentation $\left(30^{\text {th }}\right.$ day). Gas chromatographic analyses were carried out from $30^{\text {th }}$ day samples.

\subsection{Wine analytical methods}

Must and wine samples $(200 \mathrm{~mL})$ were retained from all treatment replicates (3 parallels) prior to blending and were analysed for sugar, titratable acidity (TA), $\mathrm{pH}$, and alcohol by standard methods (Amerine and Ough, 1980; Shively and Henick-Kling, 2001). Ammonium nitrogen was determined with HI 4101 ion selective electrode (Hanna Instruments). 
Table 1. Amounts of oenological additives ${ }^{\star}$ used in the experiment

\begin{tabular}{lcc}
\hline Must samples $(4 \mathrm{~L})$ & Additives on $1^{\text {st }}$ day of fermentation & Additives on $8^{\text {th }}$ day of fermentation \\
\hline 1. & $0.25 \mathrm{~g} \mathrm{DAP}$ & $0.15 \mathrm{~g} \mathrm{DAP}$ \\
2. & $0.5 \mathrm{~g}$ DAP & $0.3 \mathrm{~g} \mathrm{DAP}$ \\
3. & $0.75 \mathrm{~g} \mathrm{DAP}$ & $0.45 \mathrm{~g} \mathrm{DAP}$ \\
4. & $0.5 \mathrm{~g} \mathrm{CG}$ & $0.3 \mathrm{~g} \mathrm{CG}$ \\
5. & $1 \mathrm{~g} \mathrm{CG}$ & $0.6 \mathrm{~g} \mathrm{CG}$ \\
6. & $1.5 \mathrm{~g} \mathrm{CG}$ & $0.9 \mathrm{~g} \mathrm{CG}$ \\
7. & $0.25 \mathrm{~g} \mathrm{DAP}+1 \mathrm{~g} \mathrm{CG}$ & $0.15 \mathrm{~g} \mathrm{DAP}+0.6 \mathrm{~g} \mathrm{CG}$ \\
8. & $0.5 \mathrm{~g} \mathrm{DAP}+1 \mathrm{~g} \mathrm{CG}$ & $0.3 \mathrm{~g} \mathrm{DAP}+0.6 \mathrm{~g} \mathrm{CG}$ \\
9. & $0.75 \mathrm{~g} \mathrm{DAP}+1 \mathrm{~g} \mathrm{CG}$ & $0.45 \mathrm{~g} \mathrm{DAP}+0.6 \mathrm{~g} \mathrm{CG}$ \\
10. & $1.25 \mathrm{~g} \mathrm{ZIM}$ & $0.75 \mathrm{~g} \mathrm{ZIM}$ \\
11. & $2 \mathrm{~g}$ ZIM & $1 \mathrm{~g}$ ZIM \\
12. & $2.75 \mathrm{~g} \mathrm{ZIM}$ & $1.25 \mathrm{~g} \mathrm{ZIM}$ \\
\hline
\end{tabular}

${ }^{*}$ Additives: DAP - diammonium phosphate, CG - Creaferm Gold, ZIM - Zimovit. CG and ZIM are complex nutrients of biological nature, based on yeast-wall preparation containing assimilable nitrogen of amino-acid origin, as well as oligopeptides from yeast, growth factors (vitamins), and survival factors.

\subsection{Analyses of aroma profile of wines by gas chromatography-mass spectrometry (GC-MS)}

Sample preparation was carried out by SPME technique $(85 \mu \mathrm{m}$ Polyacrylate, Fused Silica $24 \mathrm{Ga}$ SPME fiber, adsorption: at $50^{\circ} \mathrm{C}$, for $30 \mathrm{~min}$, desorption: at $200{ }^{\circ} \mathrm{C}, 0.5 \mathrm{~min}$ ). GC-MS parameters: column: Thermo Scientific TG-5SILMS $30 \mathrm{~m} \times 0.25 \mathrm{~mm} \times 0.25 \mu \mathrm{m}$; ion source: $240^{\circ} \mathrm{C}$, ionisation: EI, scan method: FULL, from 5 min, 50-500 mass, scan times: (sec): 0.2, temperature program: $40^{\circ} \mathrm{C}$ hold $1 \mathrm{~min}, 5^{\circ} \mathrm{C} \mathrm{min}^{-1}$ to $230^{\circ} \mathrm{C}$ hold $5 \mathrm{~min}$. Splitless, Inlet: $200^{\circ} \mathrm{C}$, split flow: $50 \mathrm{~mL} \mathrm{~min}^{-1}$, split ratio: 33.3 , splitless time: $0.5 \mathrm{~min}$. Septum purge: $5 \mathrm{~mL} \mathrm{~min}^{-1}$, vacuum compensation, carrier gas (He), carrier flow: $0.8 \mathrm{~mL} \mathrm{~min}^{-1}$.

\section{RESULTS AND DISCUSSION}

\subsection{Alcoholic fermentation at different temperatures}

The fermentation of white wine varieties (Leanyka, Pinot Gris, Chardonnay) was investigated at cellar and ambient temperatures. The medium chain fatty acid content and their esters were analysed by GC-MS, results are summarised in Table 2.

In the case of all three white grape varieties, extremely high increase was observed in the concentrations of MCFAs and MCFA ethyl esters at high temperature during alcoholic fermentation. It is no accident that the suggested fermentation temperature in the production technology of white wines is under $20^{\circ} \mathrm{C}$. In accordance with current methods of wine making, our results serve as exact evidence for optimal fermentation temperature. Caproic acid (hexanoic acid), caprylic acid (octanoic acid), capric acid (decanoic acid), and their ethyl esters can be potential markers of wine fermentation problems. High concentrations of these marker compounds may refer to technological defects during wine making processes. High concentrations of 
Table 2. Effect of fermentation temperature on medium chain fatty acid and fatty acid ester contents of different white wines

\begin{tabular}{llccccc}
\hline $\begin{array}{l}\text { Grape variety and } \\
\text { fermentation } \\
\text { temperature }\end{array}$ & $\begin{array}{c}\text { Caproic acid } \\
\left(\mathrm{mg} \mathrm{L}^{-1}\right)\end{array}$ & $\begin{array}{c}\text { Caprylic acid } \\
\left(\mathrm{mg} \mathrm{L}^{-1}\right)\end{array}$ & $\begin{array}{c}\text { Capric acid } \\
\left(\mathrm{mg} \mathrm{L}^{-1}\right)\end{array}$ & $\begin{array}{c}\text { Caproic acid ethyl } \\
\text { ester }\left(\mu \mathrm{g} \mathrm{L}^{-1}\right)\end{array}$ & $\begin{array}{c}\text { Caprylic acid ethyl } \\
\text { ester }\left(\mu \mathrm{L}^{-1}\right)\end{array}$ & $\begin{array}{c}\text { Capric acid ethyl } \\
\text { ester }\left(\mu \mathrm{g} \mathrm{L}^{-1}\right)\end{array}$ \\
\hline Leanyka $\left(15-16^{\circ} \mathrm{C}\right)$ & $1.03 \pm 0.02$ & $1.21 \pm 0.12$ & $0.90 \pm 0.06$ & $10.82 \pm 1.12$ & $12.41 \pm 0.94$ & $14.30 \pm 0.9$ \\
Leanyka $\left(25-26^{\circ} \mathrm{C}\right)$ & $46.1 \pm 1.6$ & $56.2 \pm 1.9$ & $49 \pm 1.5$ & $491.40 \pm 6.50$ & $592.37 \pm 5.03$ & $554.32 \pm 5.05$ \\
Pinot Gris $\left(15-16^{\circ} \mathrm{C}\right)$ & $0.81 \pm 0.08$ & $1.18 \pm 0.07$ & $0.75 \pm 0.05$ & $9.72 \pm 0.91$ & $16.36 \pm 1.55$ & $15.41 \pm 1.3$ \\
Pinot Gris $\left(25-26^{\circ} \mathrm{C}\right)$ & $31.5 \pm 1.4$ & $35.1 \pm 1.6$ & $28.4 \pm 1.2$ & $405.01 \pm 4.28$ & $461.4 \pm 4.9$ & $484.92 \pm 5.2$ \\
Chardonnay $\left(15-16^{\circ} \mathrm{C}\right)$ & $0.62 \pm 0.09$ & $0.87 \pm 0.07$ & $0.51 \pm 0.05$ & $14.20 \pm 1.8$ & $10.56 \pm 1.0$ & $14.60 \pm 1.4$ \\
Chardonnay $\left(25-26^{\circ} \mathrm{C}\right)$ & $20.1 \pm 1.3$ & $25.7 \pm 1.8$ & $17.3 \pm 1.1$ & $374.2 \pm 5.2$ & $438.73 \pm 6.41$ & $427.70 \pm 7.1$ \\
\hline
\end{tabular}


these odorous acids and esters are undesirable; they decrease the sensory quality of white wines. Determination of optimal concentrations for middle chain fatty acids and their esters among aroma compounds is complicated since wine aromas are considered in their complexity. Yet according to our experiences, the mean concentrations of caproic acid, caprylic acid, and capric acid in quality white wines are under $5 \mathrm{mg} \mathrm{L}^{-1}$, but the available data on MCFA contents of wines in the literature is very limited. The presence of medium chain fatty acid ethyl esters on its own does not influence the sensory quality of white wines significantly (fruity flavour), yet they can be markers of faulty fermentation. Ethyl esters are formed from MCFAs in wines, high concentrations of esters refer to high concentrations of the acids. The presence of high concentrations of MCFAs or MCFA ethyl esters can cause stuck fermentation. According to our experiences, high concentrations of ethyl esters could be observed only if the concentration of the appropriate fatty acids were also high. Monitoring of either medium chain fatty acids or their esters during fermentation can be a potential way for quality control of alcoholic fermentation of white wines.

\subsection{Alcoholic fermentation applying nitrogen supplements}

In our fermentation experiments different nitrogen containing oenological additives were added to must of white grape (Chardonnay). Deliberately must of poor quality was chosen for the experiments, since the effect of additives on aroma markers was intended to be investigated. According to the usual technology of Eger Crown Winehouse Ltd., additives were added to musts in two portions, first on the starting day of the experiment, then on the eighth day. Samples were taken on the eighth day of experiment and at the end of the fermentation $\left(30^{\text {th }}\right.$ day). In both samples basic oenological parameters were measured, results are summarised in Table 3.

According to the results of the experiments it can be stated that the applied oenological additives can promote the fermentation process and fermentation occurs more stable. Sugarcontent decreased significantly after 8 days of fermentation, which resulted in the increase in alcohol-content. Applying nitrogen sources, decrease in sugar-content and increase in alcoholcontent were more significant, which meant smoother fermentation. If DAP was applied as sole nitrogen source for yeast, similar results for fermentation were obtained as when complex nitrogen-containing supplements (CG or ZIM) were used.

Medium chain fatty acid content and their esters were analysed from the $30^{\text {th }}$ day wine samples, their concentrations are shown in Table 4.

High concentrations of MCFAs and their esters were observed in wine that was fermented from Chardonnay must of poor quality (Blank experiment). Applying either DAP or complex oenological nitrogen nutrients as additives during fermentation, significant decrease in concentrations of MCFAs and their esters was experienced. The application of higher amounts of oenological additives (Samples 3, 6, 9, and 12) resulted in low concentrations of caproic acid, caprylic acid, capric acid, and their ethyl esters. Starting from must of poor quality, the application of oenological nutrients during fermentation improved the aroma profile of the resulted white wines. Lower concentrations of these marker compounds referred to the improvement of the quality of the produced wines. Determination of concentrations of middle chain fatty acids and their ethyl esters provides possibility for quality control of white wines. According to our experiences, the concentrations of caproic acid, caprylic acid, and capric acid in reductive white 
Table 3. Basic oenological parameters of musts and wines in fermentation experiments using nitrogen sources

\begin{tabular}{|c|c|c|c|c|c|c|c|c|c|c|}
\hline \multirow{2}{*}{$\begin{array}{l}\text { Samples with } \\
\text { different additives }\end{array}$} & \multicolumn{2}{|c|}{$\mathrm{pH}$} & \multicolumn{2}{|c|}{$\mathrm{TA}\left(\mathrm{g} \mathrm{L}^{-1}\right)$} & \multicolumn{2}{|c|}{ Sugar $\left(\mathrm{g} \mathrm{L}^{-1}\right)$} & \multicolumn{2}{|c|}{ Alcohol (\%) } & \multicolumn{2}{|c|}{$\begin{array}{l}\text { Ammonium } \\
\text { nitrogen }\left(\mathrm{mg} \mathrm{L}^{-1}\right)\end{array}$} \\
\hline & $8^{\text {th }}$ day & $30^{\text {th }}$ day & $8^{\text {th }}$ day & $30^{\text {th }}$ day & $8^{\text {th }}$ day & $30^{\text {th }}$ day & $8^{\text {th }}$ day & $30^{\text {th }}$ day & $8^{\text {th }}$ day & $30^{\text {th }}$ day \\
\hline Blank test* & 3.15 & 3.25 & 5.66 & 5.64 & 49.45 & 4.55 & 7.99 & 10.81 & 0.043 & 0.019 \\
\hline 1. & 3.2 & 3.20 & 5.75 & 6.03 & 43.50 & 3.46 & 8.78 & 11.05 & 0.028 & 0.029 \\
\hline 2. & 3.19 & 3.16 & 5.47 & 6.13 & 33.64 & 1.87 & 9.12 & 11.18 & 0.025 & 0.023 \\
\hline 3. & 3.18 & 3.17 & 6.0 & 6.19 & 33.65 & 2.68 & 9.25 & 11.09 & 0.034 & 0.020 \\
\hline 4. & 3.19 & 3.20 & 5.77 & 6.11 & 36.02 & 3.60 & 9.18 & 11.03 & 0.036 & 0.022 \\
\hline 5. & 3.22 & 3.19 & 5.95 & 5.97 & 23.14 & 3.27 & 10.1 & 11.04 & 0.028 & 0.018 \\
\hline 6. & 3.22 & 3.20 & 5.80 & 6.32 & 39.51 & 1.62 & 9.87 & 11.12 & 0.025 & 0.020 \\
\hline 7. & 3.20 & 3.20 & 5.85 & 6.05 & 27.85 & 1.28 & 9.98 & 11.09 & 0.027 & 0.021 \\
\hline 8. & 3.20 & 3.21 & 5.63 & 6.02 & 37.19 & 1.44 & 9.80 & 11.13 & 0.032 & 0.038 \\
\hline 9. & 3.19 & 3.21 & 5.80 & 6.06 & 29.92 & 1.75 & 9.65 & 11.06 & 0.029 & 0.028 \\
\hline 10. & 3.15 & 3.19 & 5.67 & 6.06 & 34.60 & 2.51 & 9.94 & 10.94 & 0.026 & 0.023 \\
\hline 11. & 3.12 & 3.19 & 5.93 & 6.10 & 22.43 & 1.75 & 10.48 & 11.10 & 0.042 & 0.026 \\
\hline 12. & 3.11 & 3.19 & 5.93 & 6.13 & 17.77 & 1.90 & 10.53 & 11.36 & 0.042 & 0.034 \\
\hline
\end{tabular}

*Blank (starting day): pH: 3.29; TA: $4.60 \mathrm{~g} \mathrm{~L}^{-1}$; $180 \mathrm{~g} \mathrm{~L}^{-1}$; Ammonium nitrogen: $20.17 \mathrm{mg} \mathrm{L}^{-1}$. 
Table 4. Effect of nitrogen sources during fermentation on medium chain fatty acid and fatty acid ester contents of white wine

\begin{tabular}{|c|c|c|c|c|c|c|}
\hline \multirow{2}{*}{$\begin{array}{l}\text { Wines } \\
\text { made } \\
\text { with } \\
\text { different } \\
\text { additives }\end{array}$} & \multicolumn{6}{|c|}{ Mean concentrations (3 parallel experiments) } \\
\hline & $\begin{array}{c}\text { Caproic acid } \\
\left(\mathrm{mg} \mathrm{L}^{-1}\right)\end{array}$ & $\begin{array}{l}\text { Caprylic acid } \\
\left(\mathrm{mg} \mathrm{L}^{-1}\right)\end{array}$ & $\begin{array}{l}\text { Capric acid } \\
\left(\mathrm{mg} \mathrm{L}^{-1}\right)\end{array}$ & $\begin{array}{l}\text { Caproic acid } \\
\text { ethyl ester } \\
\left(\mu \mathrm{g} \mathrm{L}^{-1}\right)\end{array}$ & $\begin{array}{l}\text { Caprylic acid } \\
\text { ethyl ester } \\
\left(\mu \mathrm{g} \mathrm{L}^{-1}\right)\end{array}$ & $\begin{array}{l}\text { Capric acid } \\
\text { ethyl ester } \\
\left(\mu \mathrm{g} \mathrm{L}^{-1}\right)\end{array}$ \\
\hline Blank & $25.08 \pm 2.52$ & $34.07 \pm 1.90$ & $29.62 \pm 2.31$ & 139.0 & $152.20 \pm 4.4$ & 130.1 \\
\hline 1. & $1.44 \pm 2.05$ & $22.93 \pm 1.84$ & $18.68 \pm 1.11$ & $78.20 \pm 2.05$ & $68.19 \pm 1.94$ & 64.90 \\
\hline 2. & $12.28 \pm 1.02$ & $10.88 \pm 1.08$ & $10.32 \pm 1.02$ & $29.20 \pm 1.08$ & $34.88 \pm 2.18$ & $32.80 \pm 1.55$ \\
\hline 3. & $7.99 \pm 0.61$ & $7.71 \pm 0.84$ & $8.95 \pm 0.58$ & $14.48 \pm 1.14$ & $16.65 \pm 1.05$ & $18.27 \pm 1.06$ \\
\hline 4. & $14.44 \pm 1.23$ & $14.67 \pm 1.48$ & $12.65 \pm 1.56$ & $55.42 \pm 1.75$ & $63.48 \pm 2.17$ & $58.24 \pm 2.51$ \\
\hline 5. & $5.57 \pm 0.55$ & $4.86 \pm 0.36$ & $7.47 \pm 0.41$ & $15.46 \pm 1.07$ & $17.38 \pm 1.26$ & $22.52 \pm 1.25$ \\
\hline 6. & $2.81 \pm 0.19$ & $1.73 \pm 0.14$ & $1.19 \pm 0.09$ & $11.23 \pm 1.16$ & $13.10 \pm 1$ & $15.63 \pm 0.92$ \\
\hline 7. & $18.49 \pm 1.58$ & $19.83 \pm 1.74$ & $16.72 \pm 1.28$ & $60.18 \pm 2.25$ & $54.44 \pm 1.74$ & $72.41 \pm 3.68$ \\
\hline 8. & $2.54 \pm 0.16$ & $3.81 \pm 0.25$ & $2.65 \pm 0.19$ & $17.72 \pm 1.02$ & $19.94 \pm 1.49$ & $25.92 \pm 1.73$ \\
\hline 9. & $0.95 \pm 0.08$ & $1.27 \pm 0.10$ & $1.58 \pm 0.12$ & $10.84 \pm 1.09$ & $12.16 \pm 1.35$ & $16.80 \pm 1.05$ \\
\hline 10. & $16.62 \pm 1.28$ & $15.83 \pm 1.48$ & $20.26 \pm 2.37$ & $52.21 \pm 2.11$ & $50.48 \pm 1.55$ & $60.18 \pm 2.10$ \\
\hline 11. & $6.32 \pm 0.41$ & $5.88 \pm 0.29$ & $6.26 \pm 0.54$ & $17.29 \pm 1.32$ & $17.73 \pm 1.28$ & $19.72 \pm 1.39$ \\
\hline 12. & $1.94 \pm 0.22$ & $1.62 \pm 0.18$ & $1.78 \pm 0.19$ & $11.93 \pm 1.01$ & $12.75 \pm 1.33$ & $14.07 \pm 1.14$ \\
\hline
\end{tabular}

wines of best quality are under $5 \mathrm{mg} \mathrm{L}^{-1}$, at least under $10 \mathrm{mg} \mathrm{L}^{-1}$. These acids in combination, above $10 \mathrm{mg} \mathrm{L}^{-1}$ concentration have significant inhibitory effect on yeasts that may lead to stuck fermentation (Baron et al., 2017; Licek et al., 2020). The concentrations of MCFA ethyl esters in quality white wines should be under $20 \mu \mathrm{gL}^{-1}$ according to our experiences. Higher concentrations of these esters do not influence the sensory quality of white wines, but higher concentrations only occur at higher concentrations of fatty acids and they are undesired odorous compounds.

\section{CONCLUSIONS}

Contents of medium chain fatty acids and their esters of white wines was investigated during alcoholic fermentation. Effect of temperature and the application of different oenological nutrients were investigated. Increasing temperature during fermentation results in increasing concentrations of medium chain fatty acids and their esters. Applying relatively high temperatures during fermentation $\left(25-26^{\circ} \mathrm{C}\right)$ resulted in undesirably high concentrations of caproic acid, caprylic acid, capric acid, and their ethyl esters. Besides decreasing the sensory value of reductive white wines, high concentrations of MFCAs can be toxic to yeast cells, therefore, fermentation can be stuck in their presence. By the measurement of MCFAs and their ethyl esters it is possible to detect elevated temperature fermentation or even faulty fermentation. By applying oenological nutrients during fermentation significant improvement in the quality of white wines can be achieved, which was also confirmed by the determination of MFCAs and their ethyl esters. Fatty acids and fatty acid esters can be potential markers of fermentation, their concentrations can be an indication of higher temperature fermentation or even possible faulty 
fermentation. By using nitrogen containing supplements significant decrease in the amount of MCFAs can be achieved that is a highlighted result of our experiments.

\section{ACKNOWLEDGEMENT}

Authors thank the financial support of GINOP-2.1.1. Grant of Eger Crown Winehouse.

\section{REFERENCES}

Amerine, M.A. and Ough, C.S. (1980). Methods for analysis of musts and wines. Wiley and Sons, New York, p. 377.

Baroň, M., Kumšta, M., Prokeš, K., Tomaškova, L., and Tomkova, M. (2017). The inhibition of Saccharomyces cerevisiae population during alcoholic fermentation of grape must by octanoic, decanoic and dodecanoic acid mixture. BIO Web of Conferences, 9: 02025.

Bely, M., Sablayrolles, J.M., and Barre, P. (1990). Automatic detection of assimilable nitrogen deficiencies during alcoholic fermentation in oenological conditions. Journal of Fermentation and Bioengineering, 70(4): 246-252.

Cramer, A.C., Vlassides, S., and Block, D.E. (2002). Kinetic model for nitrogen-limited wine fermentations. Biotechnology and Bioengineering, 77(1): 49-60.

Francis, I.L. and Newton, J.L. (2005). Determining wine aroma from compositional data. Australian Journal of Grape and Wine Research, 11(2): 114-126.

Gobert, A., Tourdot-Maréchal, R., Sparrow, C., Morge, C., and Alexandre, H. (2019). Influence of nitrogen status in wine alcoholic fermentation. Food Microbiology, 83: 71-85.

Gomez, E., Laencina, J., and Martinez, A. (1994). Vinification effects on changes in volatile compounds of wine. Journal of Food Science, 59: 406-409.

Henschke, P.A. and Jiranek, V. (1993). Yeast-metabolism of nitrogen compounds. In: Fleet, G.H. (Ed.), Wine microbiology and biotechnology, Taylor and Francis, New York, pp. 77-164.

Killian, E. and Ough, C.S. (1979). Fermentation esters - formation and retention as affected by fermentation temperature. American Journal of Enology and Viticulture, 30: 301-305.

Licek, J., Baron, M., and Sochor, J. (2020). Comparison of MCFA and other methods of terminating alcohol fermentation and their influence on the content of carbonyl compounds in wine. Molecules, 25(23): 5737.

Liu, P., Ivanova-Petropulos, V., Duan, C., and Yan, G. (2021). Effect of unsaturated fatty acids on intrametabolites and aroma compounds of Saccharomyces cerevisiae in wine fermentation. Foods, 10(2): 277.

Merkyte, V., Longo, E., Windisch, G., and Boselli, E. (2020). Phenolic compounds as markers of wine quality and authenticity. Foods, 9: 1785.

Pérez-Navarro, J., Izquierdo-Canas, P.M., Mena-Morales, A., Chacón-Vozmediano, J.L., Martínez-Gascuena, J., García-Romero, E., Hermosín-Gutiérrez, I., and Gómez-Alonso, S. (2020). Comprehensive chemical and sensory assessment of wines made from white grapes of Vitis vinifera cultivars Albillo Dorado and Montonera del Casar: a comparative study with Airén. Foods, 9: 1282.

Restrepo, S., Espinoza, L., Ceballos, A., and Urtubia, A. (2019). Production of fatty acids during alcoholic wine fermentation under selected temperature and aeration conditions. American Journal of Enology and Viticulture, 70: 169-176. 
Samoticha, J., Wojdyło, A., Chmielewska, J., and Nofer, J. (2019). Effect of different yeast strains and temperature of fermentation on basic enological parameters, polyphenols and volatile compounds of Aurore white wine. Foods, 8(12): 599.

Santamaría, P., González-Arenzana, L., Garijo, P., Gutiérrez, A.R., and López, R. (2020). Nitrogen sources added to must: effect on the fermentations and on the Tempranillo red wine quality. Fermentation, 6(3): 79.

Shively, C.E. and Henick-Kling, T. (2001). Comparison of two procedures for assay of free amino nitrogen. American Journal of Enology and Viticulture, 52(4): 400-401.

Swiegers, J.H. and Pretorius, S. (2007). Modulation of volatile sulfur compounds by wine yeast. Applied Microbiology and Biotechnology, 74(5): 954-960.

Torija, M.J., Beltran, G., Novo, M., Poblet, M., Guillamon, J.M., and Mas, A. (2003). Effects of fermentation temperature and Saccharomyces species on the cell fatty acid composition and presence of volatile compounds in wine. International Journal of Food Microbiology, 85(1-2): 127-136.

Tronchoni, J., Rozès, N., Querol, A., and Guillamón, J.M. (2012). Lipid composition of wine strains of Saccharomyces kudriavzevii and Saccharomyces cerevisiae grown at low temperature. International Journal of Food Microbiology, 155(3): 191-198.

Viegas, C.A., Rosa, M.F., Correia, I.S., and Novais, J.M. (1989). Inhibition of yeast growth by octanoic and decanoic acids produced during ethanolic fermentation. Applied and Environmental Microbiology, 55(1): 21-28.

Open Access. This is an open-access article distributed under the terms of the Creative Commons Attribution 4.0 International License (https://creativecommons.org/licenses/by/4.0/), which permits unrestricted use, distribution, and reproduction in any medium, provided the original author and source are credited, a link to the CC License is provided, and changes - if any - are indicated. (SID_1) 